Article

\title{
Carbonate Apatite Precipitation from Synthetic Municipal Wastewater
}

\author{
Jessica Ross, Lu Gao, Orysia Meouch, Essie Anthony, Divya Sutarwala, Helina Mamo and \\ Sidney Omelon * \\ Department of Chemical and Biological Engineering, University of Ottawa, Ottawa, ON K1N 6N5, Canada; \\ jross040@uottawa.ca (J.R.); lgao072@uottawa.ca (L.G.); omeou066@uottawa.ca (O.M.); \\ eanth029@uottawa.ca (E.A.); dsuta007@uottawa.ca (D.S.); hmamo018@uottawa.ca (H.M.) \\ * Correspondence: somelon@uottawa.ca; Tel.: +1-613-562-5800
}

Received: 31 May 2017; Accepted: 18 July 2017; Published: 25 July 2017

\begin{abstract}
An important component of phosphorite (phosphate rock) is carbonate apatite, as it is required for phosphorous fertilizer production due to its increased phosphate solubility caused by carbonate substitution in the apatite mineral lattice. High phosphate concentrations in municipal wastewater treatment plants are commonly reduced by precipitating iron phosphate by addition of iron chloride. We investigated the possibility of precipitating carbonate apatite from a potential range of phosphate concentrations that could be available from municipal wastewater treatment plants with anaerobic digestion reactors $(5 \mathrm{mM}-30 \mathrm{mM})$. Synthetic phosphate solutions at neutral $\mathrm{pH}$ were mixed in batch experiments with a calcium carbonate solution produced by dissolving calcite in contact with carbon dioxide gas, with and without carbonate apatite seed. Batch experiments were used to identify the carbonate apatite supersaturation ranges for homogeneous and heterogeneous nucleation, and the precipitates analyzed with Raman spectroscopy, powder X-ray diffraction, inorganic carbon coulometry, and scanning electron microscopy. Some precipitates contained carbonate weight fractions within the range reported for geological phosphate rock $(1.4-6.3 \mathrm{wt} \%)$. The precipitates were spherical, poorly crystalline carbonate apatite, suggesting an amorphous precursor transformed to a poorly crystalline carbonate apatite without changing morphology.
\end{abstract}

Keywords: amorphous precursor; nucleation; carbonate apatite; amorphous calcium carbonate phosphate

\section{Introduction}

The genesis of phosphorus-rich minerals such as carbonate apatite, which is a component of the valuable P-rich ore known as phosphorite or phosphate rock (PR), was an unanswered geological question for many years. Environmental conditions do not commonly generate inorganic orthophosphate $(\mathrm{Pi})$ concentrations high enough for spontaneous phosphate mineral nucleation events. Theorized mechanisms for PR precipitation included inorganic precipitation and biologically-mediated precipitation [1,2]. One mechanism for $\mathrm{Pi}$ concentration in the marine environment is the accumulation and storage of polyphosphates (polyP: $\left.\left(\mathrm{PO}_{3}{ }^{-}\right)_{n}\right)$ within sulfide-oxidizing bacteria (genera Thiomargarita [3] and Beggiatoa [4]) during oxic environmental conditions. Periodic flow of anoxic waters into the bacterial mats causes the bacteria to switch their metabolism to a process that breaks down their polyP stores into Pi [5]. The dissolved Pi concentration in these extracellular matrices increases, and was measured to be $300 \mu \mathrm{M}$ [6]—order of magnitudes above the average ocean Pi concentration of $<1 \mu \mathrm{M}$ [7]. When the Pi concentration increases upon polyP breakdown, the calcium and carbonate ions co-precipitate as apatite within the bacterial mat. The resultant high $\mathrm{P}$ content of ancient and modern apatite-rich ores qualifies them as PR. PR is a valuable resource because it is the only available phosphate mineral that can be economically used to produce phosphorus fertilizer, due to its increased solubility caused by its carbonate content [8]. PR is dissolved in sulfuric acid; this wet 
process produces phosphoric acid for phosphorous fertilizers [9]. The carbonate content of PR ranges from approximately 1.4-6.3 $\mathrm{wt} \% \mathrm{CO}_{3}{ }^{2-}$ [10]. PR is a valuable and non-renewable resource [11,12].

A similar biological process of Pi concentration as polyP, followed by Pi release, Pi concentration increase, and precipitation is observed in municipal wastewater treatment plants. Biological phosphorus removal processes have been developed to enhance the uptake of Pi by polyP accumulating organisms [13]. In oxic conditions, the polyP-accumulating bacteria uptake Pi and generate intracellular polyP. Upon anoxic conditions within anaerobic digester reactors, these organisms hydrolyze their intracellular polyP and release Pi into solution. The resulting increased Pi concentration is decreased before treated water is released to the environment to avoid ecological upsets [14]. Soluble di- or trivalent metal chloride salts are added to reduce the Pi concentration by precipitating metal phosphate [15], which is a component of biosolids that are produced by many municipal wastewater treatment processes. Although sometimes applied to soils, the low solubility of iron phosphate in biosolids limits Pi availability to plants [16]. This processing results in a loss of Pi to the food chain.

We wished to investigate if a carbonate apatite could be precipitated from Pi at concentrations available within municipal wastewater treatment plants with anaerobic digestion reactors (ranging from 2.5 to $30 \mathrm{mM} \mathrm{Pi}$ ), by precipitation with a dissolved calcium carbonate solution. Calcite, a calcium carbonate mineral, in equilibrium with an apatite-precipitation solution does not spontaneously precipitate a carbonate apatite product [17]. Therefore, a more concentrated calcium carbonate solution is required to generate a supersaturated solution with respect to carbonate appetite for our target Pi-concentration ([Pi]) solutions. Calcite solubility was increased by preparing a saturated solution of calcite in potable water, then contacting this slurry with gasses of different $\mathrm{CO}_{2}$ fractions that simulated flue gas $\mathrm{CO}_{2}$ concentrations that could be available at municipal wastewater treatment plants. Some municipal wastewater treatment plants with anaerobic digestion reactors produce a methane-rich biogas, and burn this biogas in an on-site electric power plant [18]. We investigated the possibility of mixing this calcium-bicarbonate-rich solution, which will be referred to as a saturated $\mathrm{Ca}-\mathrm{CO}_{3}$ solution, with representative [Pi] to precipitate a carbonate apatite mineral with a carbonate fraction similar to PR, with and without seed.

Seeding a crystallization process is expected to reduce the supersaturation required for precipitation [19]. Both protein-free biological carbonate apatite, and solids produced by homogeneous nucleation experiments were tested. This system is based on synthetic calcium, carbonate, and phosphate sources. The phosphate sources from a wastewater treatment plant contain a myriad of other chemical components which have unknown impacts on carbonate apatite precipitation with this strategy. This work was pursed to determine if the simplest case scenarios could generate carbonate apatite. Precipitation of carbonate apatite from Pi in municipal wastewater treatment streams could generate a potential useful resource for the wet-process phosphorous fertilizer industry.

\section{Materials and Methods}

\subsection{Calcium Carbonate Solution Preparation}

ACS grade calcium carbonate (identified as calcite by powder X-ray diffraction and Raman spectroscopy, MP Biomedicals, LLC, Solon, OH, USA) was mixed with potable water ( $\mathrm{pH} 9,0.2 \mathrm{mM}$ $\mathrm{Ca}^{2+}, 0.2 \mathrm{mM}$ inorganic carbon, City of Ottawa) at a concentration of $1 \mathrm{~g} \mathrm{CaCO}_{3} / \mathrm{L}$ overnight. $\mathrm{N}_{2}-\mathrm{CO}_{2}$ mixed gases with $7 \% \mathrm{CO}_{2}$ (representative of natural gas fired power plant flue gas composition [20]), $15 \% \mathrm{CO}_{2}$ (representative of the power plant flue gas composition powered by biofuel from a wastewater treatment plant [21]) and 100\% $\mathrm{CO}_{2}$ were mixed, then bubbled at a flow rate of $\sim 0.1-0.4 \mathrm{~L} / \mathrm{min}$ through $1 \mathrm{~L}$ of the calcium carbonate slurry in a closed, stirred tank reactor with a gas outlet ducted to a fume hood. The $\mathrm{pH}$ and calcium concentrations were monitored as function of time until the values stabilized. The $\mathrm{pH}$ was measured with a $\mathrm{pH}$ probe (AR10, Orion) and the calcium concentrations measured with colourimetry [22]. Samples were read from a 96 well plate by a spectrophotometer (Epoch Microplate Spectrophotometer, BioTek, Winooski, VT, USA). 


\subsection{Unseeded Carbonate Apatite Batch Precipitation}

Inorganic phosphate solutions used throughout all experiments were prepared by dissolving $\mathrm{Na}_{2} \mathrm{HPO}_{4}$ (ACS grade, Sigma-Aldrich, Oakville, ON, Canada) in distilled and deionized water. The inorganic phosphate $(\mathrm{Pi})$ concentrations used ranged from $2.5 \mathrm{mM}$ Pi to $30 \mathrm{mM} \mathrm{Pi}$, based on the Pi concentrations that are available from different municipal wastewater treatment process streams with aerobic and anaerobic sludge treatment. Pi concentrations were measured by colourimetry with the vanadomolybdate assay [23]. The batch precipitation experiments for $2.5,5,10$, and $20 \mathrm{mM} \mathrm{Pi}$ solutions were repeated four times, and the $30 \mathrm{mM}$ Pi solution batch experiment was repeated three times. The experiments are referred to with the initial Pi concentration ([Pi]) before mixing.

The different $[\mathrm{Pi}]$ solutions were mixed with an equal volume of a saturated $\mathrm{Ca}-\mathrm{CO}_{3}$ solution decanted from calcite in potable water that was mixed with $100 \% \mathrm{CO}_{2}$ for a minimum of 20 min contact time. 1:1, $250 \mathrm{~mL}$ volumes of the saturated $\mathrm{Ca}-\mathrm{CO}_{3}$ and Pi-solutions were mixed in a beaker at room temperature, sealed, and gently shaken. An aliquot was taken of each of the initial solutions prior to mixing to calculate the theoretical initial mixed concentration, and 5 days after mixing. A 5 day contact time was selected to ensure that precursor amorphous phases would recrystallize to apatite, as this transition has been reported to occur within $48 \mathrm{~h}[24,25]$. The initial and final $\mathrm{pH}$ values were recorded. The $\mathrm{pH}$ was not controlled during these series of experiments. The difference in initial and final $\left[\mathrm{Ca}^{2+}\right]$ and $[\mathrm{Pi}]$ were used to calculate percentage changes, and to calculate the theoretical precipitate molar $\mathrm{Ca} / \mathrm{P}$ ratio obtained by the reduction in $\left[\mathrm{Ca}^{2+}\right]$ and $[\mathrm{Pi}]$. Observations regarding whether or not precipitate was immediately visible and if scale formed on the glassware surfaces were noted, as this would indicate whether the saturation state with respect to carbonate apatite was sufficient for heterogeneous nucleation on glass surfaces and other contaminants, or above the critical supersaturation for homogeneous nucleation. After five days, the slurries were vacuum-filtered through a glass filter, rinsed with deionized and distilled water, and vacuum-dried at $40{ }^{\circ} \mathrm{C}$ and $5 \mathrm{~mm} \mathrm{Hg}$.

The solubility product and the ion activity product are used to calculate the supersaturation of a given salt [26]. Since the exact composition and solubility product of carbonate apatite are unknown, a simplification of the supersaturation index will be used to compare the saturation states. The measured calcium concentration $\left(\left[\mathrm{Ca}^{2+}\right]\right)$ multiplied by the inorganic phosphate concentration $\left(\left[\mathrm{Ca}^{2+}\right] \times[\mathrm{Pi}]\right)$ will be used as a proxy saturation index, as the dissolved carbonate concentration is challenging to measure accurately. This is an oversimplification of a complex problem. As the carbonate substitution for phosphate or hydroxyl molecules is not known, stoichiometric coefficients will not be used in this saturation index, as used by Fleisch [27].

The goal of this work is to determine if mixing a saturated $\mathrm{Ca}-\mathrm{CO}_{3}$ solution produced by calcite in potable water that was in contact with $\mathrm{CO}_{2}$ gas, with different $[\mathrm{Pi}]$ solutions generates a supersaturation large enough to spontaneously produce a synthetic PR analogue material through homogeneous nucleation. If possible, then heterogeneous precipitation in the presence of seed would also be possible, because this condition requires a lower supersaturation.

\subsection{Seeded Carbonate Apatite Batch Precipitation}

Given that the supersaturation required for heterogeneous nucleation is lower than that required for homogeneous nucleation, seeded, batch precipitation tests were undertaken to determine if crystal growth could occur with the lowest and highest supersaturation conditions that generated spontaneous precipitation $(5 \mathrm{mM}$ and $30 \mathrm{mM} \mathrm{Pi})$. As the desired final precipitate is a carbonate apatite, it was assumed that biological apatite, which has a higher substituted carbonate fraction in carbonate apatite than PR (5-9 wt \% $\left.\mathrm{CO}_{3}{ }^{2-}[28,29]\right)$, could be a suitable seed material. The unseeded batch precipitation procedure was followed with the addition of 0.5 or $2 \mathrm{~g} / \mathrm{L}$ bone mineral in the batch experiment. These seeded experiments were performed in duplicate.

To prepare the bone mineral, bovine bone was crushed, Tris-washed, lyophilized, and defatted in a 2:1 chloroform:methanol solution. The bone powder was deproteinized with bleach, rinsed with 
distilled and deionized water, and dried in a vacuum oven at less than $100{ }^{\circ} \mathrm{C}$. The final product was ground with a mortar and pestle, and the fraction that passed below a $63 \mu \mathrm{m}$ sieve was used as seed. A second set of batch precipitation experiments was undertaken, seeded with precipitates produced by an unseeded batch precipitation (referred to as "ppt"). This precipitation was induced by mixing $1 \mathrm{~L}$ of $27 \mathrm{mM} \mathrm{Pi}$ (similar to a known [Pi] in a local municipal wastewater treatment plant stream) with $1 \mathrm{~L}$ of $6 \mathrm{mM} \mathrm{Ca}^{2+}$ solution from $\mathrm{CaCO}_{3(\mathrm{~s})}$ dissolution in potable water (initial concentration $8 \mathrm{mg} / \mathrm{L}$ $\left.(0.2 \mathrm{mM}) \mathrm{Ca}^{2+}, \mathrm{pH} 9\right)$ in equilibrium with $100 \% \mathrm{CO}_{2}$. The precipitate was vacuum filtered, rinsed with distilled and deionized water, and dried in a vacuum oven at $40{ }^{\circ} \mathrm{C}$ and $5 \mathrm{~mm} \mathrm{Hg}$. This seed was used in the $5 \mathrm{mM}$ initial [Pi] test, as it was expected to provide surface chemistry with a closer match to solid phase favored to grow in these conditions. Precipitate produced from this seeded, batch crystallization experiment was used as seed for a $7 \mathrm{mM}$ initial [Pi] batch crystallization experiment, which is characteristic of the lowest [Pi] in a local municipal wastewater treatment plant stream.

\subsection{Precipitate Characterization}

As bone mineral is composed of a higher carbonate weight fraction than PR, only unseeded precipitates and precipitates seeded with homogeneously nucleated seed were characterized in order to avoid confounding the new precipitate chemistry with the bone mineral seed chemistry.

\subsubsection{Scanning Electron Microscopy}

Samples were dried, mounted with carbon tape, and secondary electron images taken (Phenom PRO, Pheonom-World, Eindhoven, The Netherlands) at magnifications of $165 \times, 500 \times$, and $1000 \times$. The images were scanned at $10 \mathrm{kV}$ and a resolution of $2048 \mathrm{dpi}$, with an exposure time of $26 \mathrm{~s}$.

\subsubsection{Raman Spectroscopy}

Raman spectroscopy was undertaken with a WITec Alpha 300 confocal microscope with a $20 \times$ lens (WITec GmbH, Ulm, Germany). The laser source used was either $785 \mathrm{~nm}$ (XTRA High Power Single Frequency Diode Laser, Toptica Photonics, Victor, NY, USA), 488, or 532 nm (WITec GmbH, Ulm, Germany). Calibration was performed on the $520 \mathrm{~nm}$ Raman shift of Si.

Dry powdered samples were placed on a quartz slide, and data was collected with an integration time of $1 \mathrm{~s}$ for a minimum of $45 \mathrm{~s}$. The Raman shifts of greatest interest were $960 \mathrm{~cm}^{-1}$ for the Pi identification in apatite, $1070 \mathrm{~cm}^{-1}$ for carbonate in apatite, and $1090 \mathrm{~cm}^{-1}$ for carbonate in calcite. Silicon, synthetic hydroxyapatite (HAP, Sigma-Aldrich, Oakville, ON, Canada), calcite $\left(\mathrm{CaCO}_{3}, \mathrm{MP}\right.$ Biomedicals, LLC, Solon, $\left.\mathrm{OH}, \mathrm{USA}\right)$, and bone powder were used as standard materials. The resulting spectra were filtered to remove cosmic ray interference. OPUS Spectroscopy software (v 6.5, Bruker Optiks, Ettlingen, Germany) was used to remove the baseline, smooth (9 smoothing points) slightly, and normalize the spectra that were then plotted with OriginPro 9.1 (OriginLab Corporation, Northampton, MA, USA).

\subsubsection{Powder X-ray Diffraction}

Precipitates were analyzed with a Multiflex D3 (Rigaku Americas Corporation, The Woodlands, TX, USA). The products were prepared on a low-background Si sample-holder, and scanned between $20-45^{\circ} 2 \theta$ at a scan rate of $1^{\circ} / \mathrm{min}$. The raw data were compared with ICDD PDF file for hydroxyapatite with PDXL 2 (Version 2.5.1.2, Rigaku Americas Corporation, The Woodlands, TX, USA).

\subsubsection{Inorganic Carbon Coulometry}

A carbon coulometer (Model \#5012) (UIC Inc., Joliet, IL, USA) was used to measure the weight percent carbonate of the precipitates. A measured sample mass was dissolved in a $\mathrm{CO}_{2}$-free chamber with $2 \mathrm{M}$ perchloric acid $\left(\mathrm{HClO}_{4}\right.$, Sigma-Aldrich, Oakville, ON, Canada), and the $\mathrm{CO}_{2}$ gas evolved from carbonate ions ${ }^{-}$passed to another chamber to be quantified. Quantification of $\mathrm{CO}_{2}(\mathrm{~g})$ is 
accomplished by a titration reaction that is neutralized by redox reaction. The coulombs required for titration are proportional to the number of $\mathrm{CO}_{2}(\mathrm{~g})$ molecules that initiated the titration reaction. The coulometer calculates the mass of carbonate from titrated $\mathrm{CO}_{2}$, allowing for the calculation of the weight percent carbonate.

\subsubsection{Solubility}

A few milligrams of precipitates were dissolved in $5 \mathrm{~mL}$ of distilled and deionized $\mathrm{H}_{2} \mathrm{O}$ for one week under gentle mechanical shaking so they could reach equilibrium with the solution. The colorimetric methods were used to measure the resulting $\left[\mathrm{Ca}^{2+}\right]$ and $[\mathrm{Pi}]$ that were assumed to be in equilibrium with the precipitates. These values were used to calculate $\left[\mathrm{Ca}^{2+}\right] \times[\mathrm{Pi}]$ values, as well as the molar ratio of $\mathrm{Ca} / \mathrm{P}$ in solution.

\section{Results}

\subsection{Calcium Carbonate Solution Preparation}

Figure 1 presents an example of initial conditions and the changes in $\mathrm{pH}$ and $\left[\mathrm{Ca}^{2+}\right]$ with time during contact with $100 \% \mathrm{CO}_{2}$. Table 1 presents the equilibrium $\left[\mathrm{Ca}^{2+}\right]$ and $\mathrm{pH}$ for the different $\%$ $\mathrm{CO}_{2}$ values.

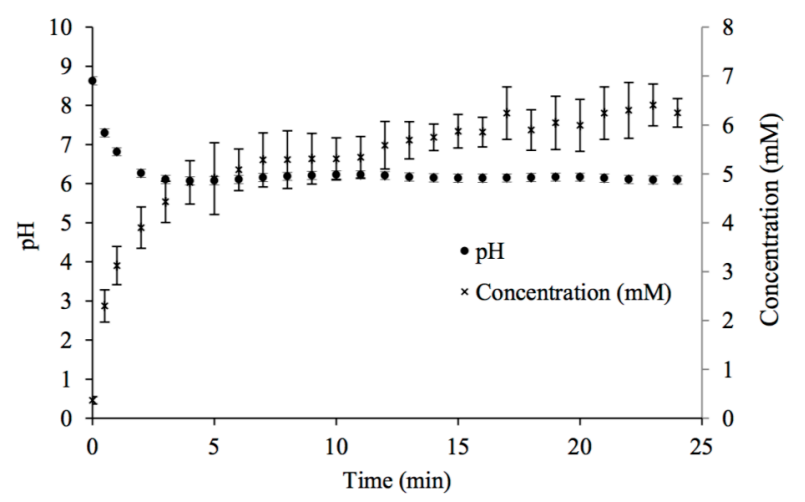

Figure 1. Changes in $\mathrm{pH}$ and calcium concentration with time in potable water mixed with $\mathrm{CaCO}_{3(\mathrm{~s})}$ while in contact with $100 \% \mathrm{CO}_{2}$ gas at room temperature.

Table 1. Effect of percent $\mathrm{CO}_{2}$ on the equilibrium $\left[\mathrm{Ca}^{2+}\right]$ and $\mathrm{pH}$ of saturated $\mathrm{Ca}-\mathrm{CO}_{3}$-potable water solutions.

\begin{tabular}{ccc}
\hline$\% \mathbf{C O}_{\mathbf{2}}$ & {$\left[\mathrm{Ca}^{2+}\right](\mathbf{m M})$} & $\mathbf{p H}$ \\
\hline 0 & $0.37 \pm 0.1$ & 8.0 \\
$7 \pm 2$ & $3.6 \pm 0.7$ & $6.7 \pm 0.1$ \\
$15 \pm 2$ & $4.8 \pm 0.4$ & $6.3 \pm 0.1$ \\
100 & $5.7 \pm 0.4$ & $6.2 \pm 0.1$ \\
\hline
\end{tabular}

Solutions from the $100 \% \mathrm{CO}_{2}$ experiments were used as calcium and carbonate sources in the subsequent carbonate apatite batch precipitation experiments. $\mathrm{Ca}-\mathrm{CO}_{3}$ saturated solutions were used as soon as possible after their production, as calcium carbonate precipitates from the decanted solutions as they shift to equilibrium with the atmosphere.

\subsection{Unseeded Carbonate Apatite Batch Precipitation}

The initial and final concentrations of calcium and $\mathrm{Pi}$ in the batch precipitation experiments, as well as the final $\mathrm{pH}$, the theoretical percent calcium and Pi removed from solution, and the theoretical $\mathrm{Ca} / \mathrm{P}$ in the precipitate are listed in Tables $2-4$. Before mixing, the average $\left[\mathrm{Ca}^{2+}\right]$ from $\mathrm{CaCO}_{3}$ solutions 
used was $6 \pm 1 \mathrm{mM}$, while the target [Pi]s were $2.5,5,10,20$, or $30 \mathrm{mM}$. Note that the sample names reflect the initial $[\mathrm{Pi}]$ before mixing with the saturated $\mathrm{Ca}-\mathrm{CO}_{3}$ solution.

Table 2. Summary of $\left[\mathrm{Ca}^{2+}\right]$ results for the batch, unseeded precipitation tests.

\begin{tabular}{cccc}
\hline [Pi] Solution $(\mathbf{m M})$ & Initial $\left[\mathbf{C a}^{2+}\right] \mathbf{( m M )}$ & Final $\left.\left[\mathbf{C a}^{2+}\right] \mathbf{( m M}\right)$ & Percent $\left[\mathbf{C a}^{2+}\right]$ Change \\
\hline 2.5 & $2.89 \pm 0.43$ & $2.07 \pm 0.24$ & $-17 \%$ \\
5 & $2.59 \pm 0.50$ & $1.14 \pm 0.71$ & $-56 \%$ \\
10 & $2.68 \pm 0.40$ & $0.36 \pm 0.20$ & $-87 \%$ \\
20 & $2.67 \pm 0.38$ & $0.15 \pm 0.06$ & $-94 \%$ \\
30 & $2.40 \pm 0.18$ & $0.05 \pm 0.01$ & $-98 \%$ \\
\hline
\end{tabular}

Table 3. Summary of [Pi] results for the batch, unseeded precipitation tests.

\begin{tabular}{cccc}
\hline [Pi] Solution (mM) & Initial [Pi] $\mathbf{( m M )}$ & Final [Pi] $\mathbf{( m M )}$ & Percent [Pi] Change \\
\hline 2.5 & $1.24 \pm 0.02$ & $0.94 \pm 0.28$ & $-24 \%$ \\
5 & $2.45 \pm 0.07$ & $1.44 \pm 0.32$ & $-41 \%$ \\
10 & $5.07 \pm 0.44$ & $3.38 \pm 0.19$ & $-33 \%$ \\
20 & $11.10 \pm 0.93$ & $8.67 \pm 0.29$ & $-22 \%$ \\
30 & $15.06 \pm 0.01$ & $13.46 \pm 0.26$ & $-11 \%$ \\
\hline
\end{tabular}

Table 4. Summary of $\mathrm{pH}$ and theoretical $\mathrm{Ca} / \mathrm{P}$ results for the batch, unseeded precipitation tests.

\begin{tabular}{ccc}
\hline [Pi] Solution $(\mathbf{m M})$ & Final $\mathbf{p H}$ & Theoretical Precipitate Ca/P \\
\hline 2.5 & $7.07 \pm 0.19$ & $1.84 \pm 0.86$ \\
5 & $6.95 \pm 0.21$ & $1.47 \pm 0.23$ \\
10 & $7.21 \pm 0.15$ & $1.46 \pm 0.43$ \\
20 & $7.34 \pm 0.18$ & $1.08 \pm 0.19$ \\
30 & $7.5 \pm 0.08$ & $1.48 \pm 0.18$ \\
\hline
\end{tabular}

The concentration changes are shown graphically in Figure 2, where it becomes apparent with the different final $\left[\mathrm{Ca}^{2+}\right]$ (arrow head) that the limiting reagent is different above and below the case $[\mathrm{Pi}]=5 \mathrm{mM}$. For $[\mathrm{Pi}]$ of $5 \mathrm{mM}$ or less, only $56-17 \%$ of the initial mixed $\left[\mathrm{Ca}^{2+}\right]$ precipitated from the solution, whereas $98-94 \%$ of the $\left[\mathrm{Ca}^{2+}\right]$ is reduced when mixed with [Pi] $>10 \mathrm{mM}$. When the mixed $[\mathrm{Pi}]$ is higher than the $\left[\mathrm{Ca}^{2+}\right]$, the reaction is limited by the $\left[\mathrm{Ca}^{2+}\right]$. The $\mathrm{pH}$ is likely buffered by the residual $[\mathrm{Pi}$ ] and carbonate. The different theoretical $\mathrm{Ca} / \mathrm{P}$ ratios calculated by the loss of these ions from solution also suggest that there is a range in this theoretically calculated chemical composition for the homogeneously nucleated precipitate phases, as the theoretical precipitate $\mathrm{Ca} / \mathrm{P}$ values are not statistically significantly different (one-way ANOVA, with Bonferroni means comparison).

If the initial [Pi] was $10 \mathrm{mM}$ or higher, the solution became cloudy immediately upon mixing with the $\mathrm{Ca}-\mathrm{CO}_{3}$ solution. This indicated that a supersaturation state above the critical supersaturation for homogeneous nucleation was achieved $\left(S_{\text {critical }}\right.$, Figure 2$)$. With initial $[\mathrm{Pi}]=5 \mathrm{mM}$, there was no evidence of homogeneous nucleation, but precipitate formed on the beaker walls. This would suggest that the experimental conditions for the metastable zone, below $S_{\text {critical }}$ at an initial [Pi] $=5 \mathrm{mM}$, and above carbonate apatite saturation were identified. The $2.5 \mathrm{mM}$ initial [Pi] experiment did not produce enough solids to be collected and quantified, but the measurable decrease in both $\left[\mathrm{Ca}^{2+}\right]$ and $[\mathrm{Pi}]$ suggests that heterogeneous precipitation occurred. It was assumed that $S_{\text {critical }}$ in this system lies between an initial [Pi] between 5 and $10 \mathrm{mM}$ before mixing (2.5 and $5 \mathrm{mM}$ after mixing), and [Ca $\left.{ }^{2+}\right]$ of $3 \mathrm{mM}$ after mixing (dashed vertical line in Figure 2). For this system, $\mathrm{S}_{\text {critical }}$ with the simplified index $\left[\mathrm{Ca}^{2+}\right] \times[\mathrm{Pi}]$ lies between 7.5 and $15 \mathrm{mM}^{2}$. 


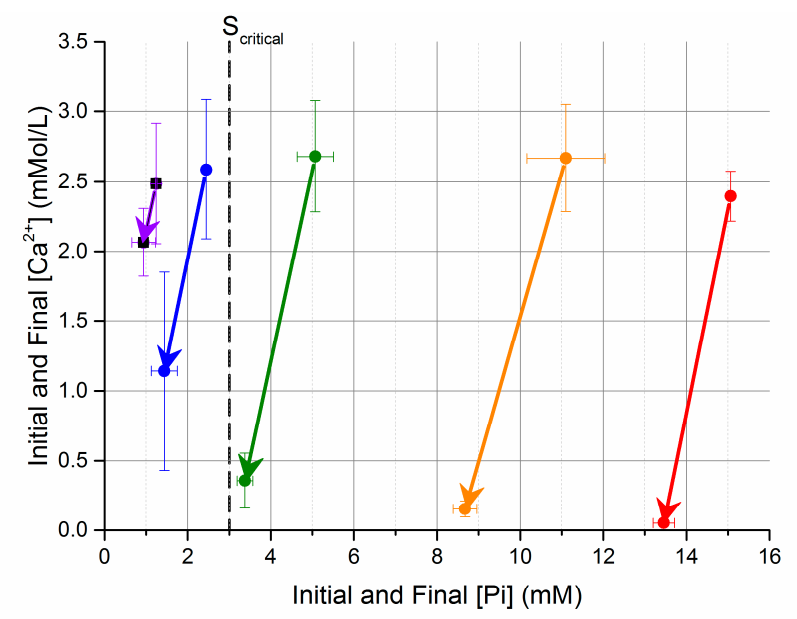

$\longrightarrow-2.5 \mathrm{mM} \mathrm{Pi} \longrightarrow-0 \mathrm{mM} \mathrm{Pi} \longrightarrow-10 \mathrm{mM} \mathrm{Pi} \longrightarrow-20 \mathrm{mM} \mathrm{Pi} \longrightarrow-30 \mathrm{mM} \mathrm{Pi}$

Figure 2. Change in $\left[\mathrm{Ca}^{2+}\right]$ and $[\mathrm{Pi}]$ after five days in unseeded batch precipitation. The samples are named after the $[\mathrm{Pi}]$ before mixing with the $\mathrm{Ca}-\mathrm{CO}_{3}$ solution.

\subsection{Seeded Carbonate Apatite Batch Precipitation}

The initial and final concentrations of calcium and $\mathrm{Pi}$ in the seeded batch precipitation experiments, initial and final $\mathrm{pH}$, percent calcium and $\mathrm{Pi}$ removed from solution, and the calculated $\mathrm{Ca} / \mathrm{P}$ in the precipitate are listed in Tables 5-7. The maximum $\left[\mathrm{Ca}^{2+}\right]$ from $\mathrm{Ca}-\mathrm{CO}_{3}$ solutions used was $6 \pm 1 \mathrm{mM}$, while the [Pi] solution concentrations were 5,7 , or $30 \mathrm{mM}$ before mixing with the $\mathrm{Ca}-\mathrm{CO}_{3}$ solution.

Table 5. Summary of $\left[\mathrm{Ca}^{2+}\right]$ results for the batch, seeded precipitation tests.

\begin{tabular}{ccccc}
\hline $\begin{array}{c}\text { [Pi] Solution } \\
(\mathbf{m M})\end{array}$ & $\begin{array}{c}\text { [Seed] }(\mathrm{g} / \mathrm{L}) \\
\text { \& Type }\end{array}$ & $\begin{array}{c}\text { Initial }\left[\mathrm{Ca}^{2+}\right] \\
(\mathbf{m M})\end{array}$ & Final $\left[\mathrm{Ca}^{2+}\right](\mathbf{m M})$ & $\begin{array}{c}\text { Percent }\left[\mathrm{Ca}^{2+}\right] \\
\text { Change }\end{array}$ \\
\hline $5^{1}$ & $0.50($ bone) & 3.06 & 1.11 & $-64 \%$ \\
$5^{1}$ & $2.0(\mathrm{bone})$ & 3.03 & 1.09 & $-64 \%$ \\
$5^{1}$ & $1.0(\mathrm{ppt})$ & 2.96 & 0.26 & $-91 \%$ \\
$7^{2}$ & $1.0(\mathrm{ppt})$ & $2.24 \pm 0.14$ & $0.01 \pm 0.01$ & $-100 \%$ \\
$30^{1}$ & $0.50(\mathrm{bone})$ & 3.10 & 0.12 & $-96 \%$ \\
$30^{1}$ & $2.0(\mathrm{bone})$ & 3.37 & 0.09 & $-97 \%$ \\
\hline
\end{tabular}

Table 6. Summary of [Pi] results for the batch, seeded precipitation tests.

\begin{tabular}{ccccc}
\hline $\begin{array}{c}\text { [Pi] Solution } \\
(\mathbf{m M})\end{array}$ & $\begin{array}{c}\text { [Seed] }(\mathbf{g} / \mathbf{L}) \\
\text { \& Type }\end{array}$ & Initial [Pi] (mM) & Final [Pi] (mM) & $\begin{array}{c}\text { Percent [Pi] } \\
\text { Change }\end{array}$ \\
\hline $5^{1}$ & $0.50($ bone) & 2.53 & 1.16 & $-54 \%$ \\
$5^{1}$ & $2.0(\mathrm{bone})$ & 2.53 & 1.11 & $-56 \%$ \\
$5^{1}$ & $1.0(\mathrm{ppt})$ & 2.29 & 0.73 & $-68 \%$ \\
$7^{2}$ & $1.0(\mathrm{ppt})$ & 3.56 & $2.9 \pm 0.03$ & $-41 \%$ \\
$30^{1}$ & $0.50(\mathrm{bone})$ & 15.30 & 11.59 & $-24 \%$ \\
$30^{1}$ & $2.0(\mathrm{bone})$ & 15.13 & 11.09 & $-27 \%$ \\
\hline
\end{tabular}


Table 7. Summary of $\mathrm{pH}$ and theoretical $\mathrm{Ca} / \mathrm{P}$ results for the batch, seeded precipitation tests.

\begin{tabular}{cccc}
\hline [Pi] Solution (mM) & [Seed] (g/L) \& Type & Final $\mathbf{~ H ~}$ & Theoretical Precipitate Ca/P \\
\hline $5^{1}$ & $0.5($ bone) & 7.06 & 1.44 \\
$5^{1}$ & $2(\mathrm{bone})$ & 7.06 & 0.95 \\
$5^{1}$ & $1(\mathrm{ppt})$ & 7.56 & 1.74 \\
$7^{2}$ & $1(\mathrm{ppt})$ & $8.23 \pm 0.05$ & 1.52 \\
$30^{1}$ & $0.5(\mathrm{bone})$ & 7.55 & 0.81 \\
$30^{1}$ & $2(\mathrm{bone})$ & 7.67 & 0.86 \\
\hline \multicolumn{2}{r}{$n=2,^{2} n=4}$.
\end{tabular}

An increase in bone seed concentration did not dramatically increase the percent $\left[\mathrm{Ca}^{2+}\right]$ or $[\mathrm{Pi}]$ reduction, but did reduce the theoretical precipitate $\mathrm{Ca} / \mathrm{P}$ from 1.44 to 0.95 .5 and $7 \mathrm{mM}$ [Pi] solutions seeded with homogeneously nucleated precipitate $(\mathrm{ppt})$ increased the equilibrium $\mathrm{pH}$ and reduced the equilibrium $\left[\mathrm{Ca}^{2+}\right] \times[\mathrm{Pi}]($ Table 8$)$. Figure 3 compares the $\left[\mathrm{Ca}^{2+}\right]$ and $[\mathrm{Pi}]$ changes for the bone mineraland precipitate-seeded experiments; it highlights the additional $\left[\mathrm{Ca}^{2+}\right]$ reduction with ppt-seeded experiments, and the small effect of increased bone mineral seed concentration on the equilibrium solution composition.

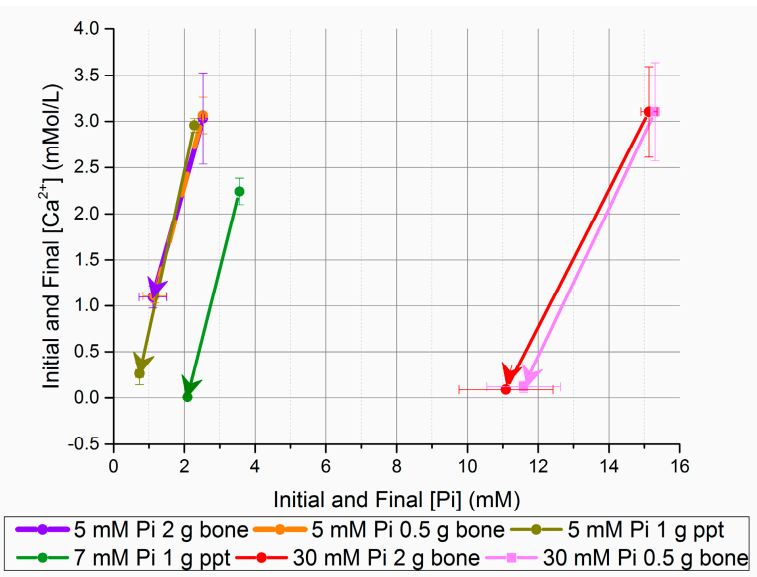

Figure 3. Change in $\left[\mathrm{Ca}^{2+}\right]$ and $[\mathrm{Pi}]$ after five days in seeded batch precipitation (bone and homogeneously nucleated precipitate (ppt)).

The simplified saturation index $\left(\left[\mathrm{Ca}^{2+}\right] \times[\mathrm{Pi}]\right)$ and final $\mathrm{pH}$ for the seeded and unseeded experiments are listed in Table 8.

Table 8. Measured $\left[\mathrm{Ca}^{2+}\right] \times[\mathrm{Pi}]$ values before and after batch precipitation experiments.

\begin{tabular}{|c|c|c|c|c|}
\hline $\begin{array}{l}\text { [Pi] Solution } \\
(\mathrm{mM})\end{array}$ & $\begin{array}{c}\text { [Seed] }(\mathrm{g} / \mathrm{L}) \\
\text { \& Type }\end{array}$ & $\begin{array}{l}{\left[\mathrm{Ca}^{2+}\right] \times[\mathrm{Pi}]} \\
\text { Initial }(\mathrm{mM})^{2}\end{array}$ & $\begin{array}{l}{\left[\mathrm{Ca}^{2+}\right] \times[\mathrm{Pi}]} \\
\text { Final }(\mathrm{mM})^{2}\end{array}$ & Final $\mathrm{pH}$ \\
\hline $2.5^{1}$ & 0 & $3.09 \pm 0.51$ & $1.90 \pm 0.48$ & $7.07 \pm 0.19$ \\
\hline $5^{1}$ & 0 & $6.36 \pm 1.38$ & $1.73 \pm 1.40$ & $6.95 \pm 0.21$ \\
\hline $5^{2}$ & 0.50 (bone) & 7.73 & 1.25 & 7.06 \\
\hline $5^{2}$ & 2.0 (bone) & 7.65 & 1.19 & 7.06 \\
\hline $5^{2}$ & $1.0(\mathrm{ppt})$ & 6.75 & 0.20 & 7.56 \\
\hline $7^{2}$ & $1.0(\mathrm{ppt})$ & 7.98 & 0.02 & $8.23 \pm 0.05$ \\
\hline $10^{1}$ & 0 & $13.6 \pm 2.64$ & $1.19 \pm 0.61$ & $7.21 \pm 0.15$ \\
\hline $20^{1}$ & 0 & $29.9 \pm 6.71$ & $1.35 \pm 0.54$ & $7.34 \pm 0.48$ \\
\hline $30^{1}$ & 0 & $36.1 \pm 2.69$ & $0.70 \pm 0.11$ & $7.50 \pm 0.08$ \\
\hline $30^{2}$ & 0.50 (bone) & 47.5 & 1.41 & 7.55 \\
\hline $30^{2}$ & 2.0 (bone) & 45.9 & 0.99 & 7.67 \\
\hline
\end{tabular}


These initial and final $\left[\mathrm{Ca}^{2+}\right] \times[\mathrm{Pi}]$ data plotted with respect to the initial and final $[\mathrm{Pi}]$ are summarized in Figure 4a,b.

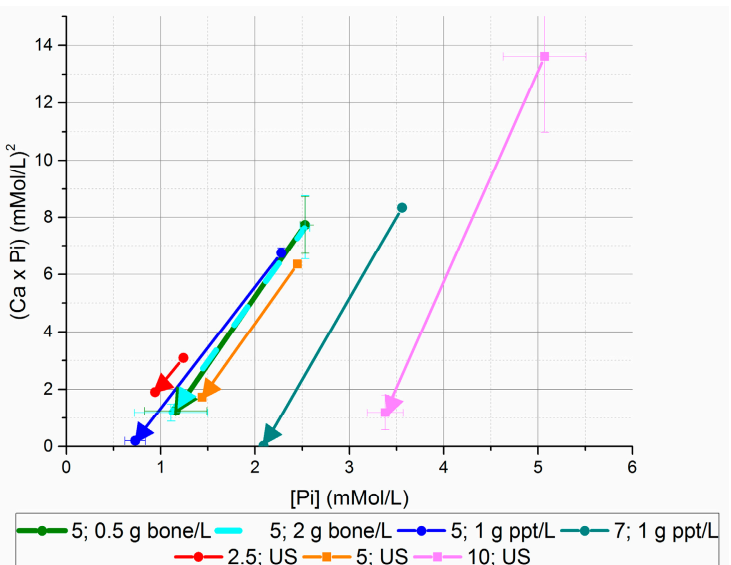

(a)

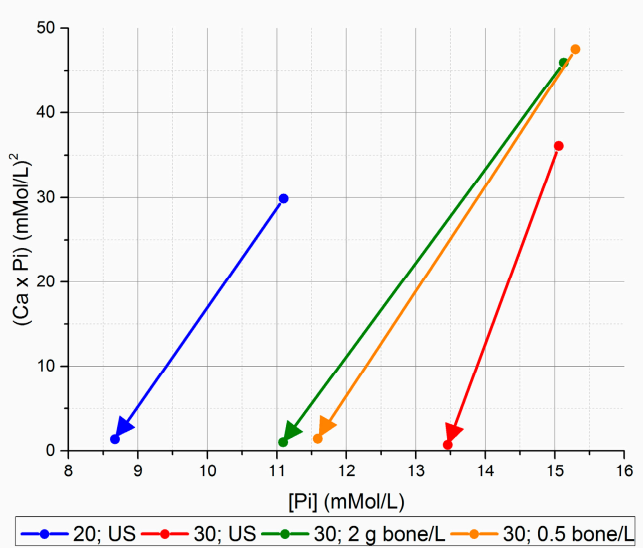

(b)

Figure 4. Initial and final $(\mathrm{Ca} \times \mathrm{P})$ values, versus initial and final [Pi] $((\mathbf{a})$ initial $[\mathrm{Pi}]<20 \mathrm{mM},(\mathbf{b})$ initial $[\mathrm{Pi}] \geq 20 \mathrm{mM})$. Using seed from previous unseeded experiments generated lower final $\left[\mathrm{Ca}^{2+}\right] \times[\mathrm{Pi}]$ values than bone mineral seed or no seed for equivalent initial [Pi].

All final $\left[\mathrm{Ca}^{2+}\right] \times[\mathrm{Pi}]$ concentrations for bone mineral-seeded and unseeded precipitation experiments were at or higher than $1 \mathrm{mM}^{2}$ except for the $30 \mathrm{mM}$ initial [Pi], unseeded experiment. Bone mineral seed lowered the final $\left[\mathrm{Ca}^{2+}\right] \times[\mathrm{Pi}]$ value for the $5 \mathrm{mM}[\mathrm{Pi}]$ experiment, but not the $30 \mathrm{mM}$ $[\mathrm{Pi}]$ experiment. The lowest final $\left[\mathrm{Ca}^{2+}\right] \times[\mathrm{Pi}]$ values were achieved with the use of precipitate seed from previous unseeded experiments, where the values were $0.2 \mathrm{mM}^{2}$ or less for initial concentrations of 5 and $7 \mathrm{mM}$ initial [Pi].

The $\mathrm{pH}$ followed an inverse trend of final $\left[\mathrm{Ca}^{2+}\right] \times[\mathrm{Pi}]$, with the highest $\mathrm{pH}$ values associated with the $7 \mathrm{mM}$ initial [Pi] group with precipitate seed, and the $30 \mathrm{mM}$ initial [Pi] unseeded precipitations. A plot of the final $\left[\mathrm{Ca}^{2+}\right] \times[\mathrm{Pi}]$ values vs. $\mathrm{pH}$ (Figure 5) shows the correlations for the increase in $\mathrm{pH}$ with decrease in $\left[\mathrm{Ca}^{2+}\right] \times[\mathrm{Pi}]$. This reflects the increase in $\left[\mathrm{PO}_{4}{ }^{3-}\right]$ and $\left[\mathrm{CO}_{3}{ }^{2-}\right]$ equilibrium speciation with increasing $\mathrm{pH}$ that would be expected to decrease the equilibrium [Pi] above apatite saturation.

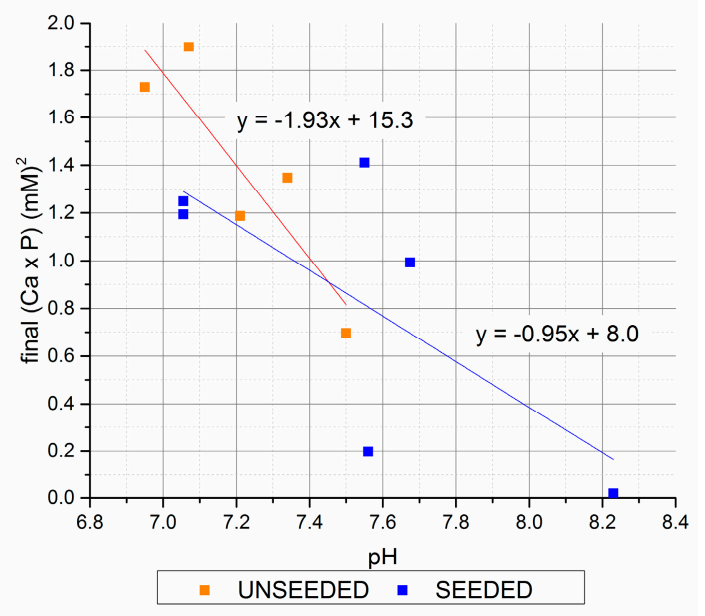

Figure 5. Final $(\mathrm{Ca} \times \mathrm{P})$ versus final $\mathrm{pH}$ (seeded and unseeded).

The different slopes of the linear regression lines for the seeded and unseeded precipitation cases suggests a possible effect of the seed chemistry on the solution chemistry. 


\subsection{Precipitate Characterization}

\subsubsection{Scanning Electron Microscopy}

Representative images for 5 and $30 \mathrm{mM}$ initial [Pi] (unseeded) and $7 \mathrm{mM}$ (seeded) taken at 5000× magnification are presented in Figure 6. Products produced at intermediate initial [Pi] were similar to the $30 \mathrm{mM}$ results. Additional SEM images of unseeded and precipitate-seeded experiments are presented in Appendix A, Figure A1.

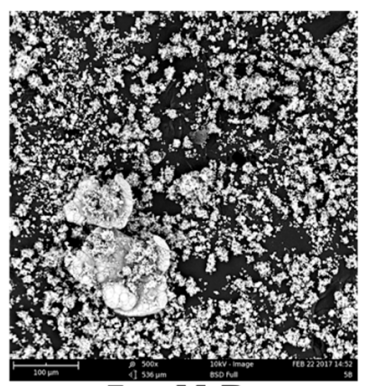

(a)

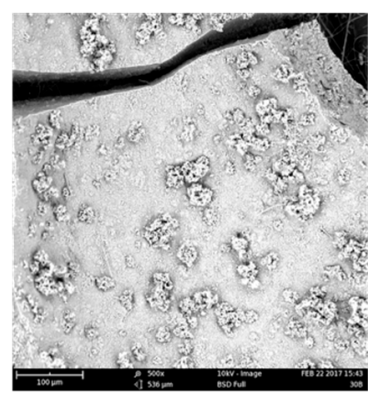

(b)

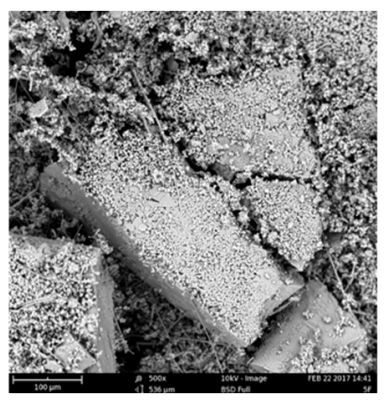

(c)

Figure 6. SEM images of precipitates from unseeded experiments (a) $5 \mathrm{mM}$; (b) $30 \mathrm{mM}[\mathrm{Pi}]$ and precipitate-seeded experiments (c) $7 \mathrm{mM}[\mathrm{Pi}]$.

An example of higher-resolution images of the seeded precipitate from the $7 \mathrm{mM}$ [Pi] experiment are shown in Figure 7. As the crystal habit for synthetic carbonate apatite is plate-like [30], the spherical solids, ranging in diameter from approximately 2 to $7 \mu \mathrm{m}$, suggest the preservation of the spherical structure characteristic of an amorphous precursor.

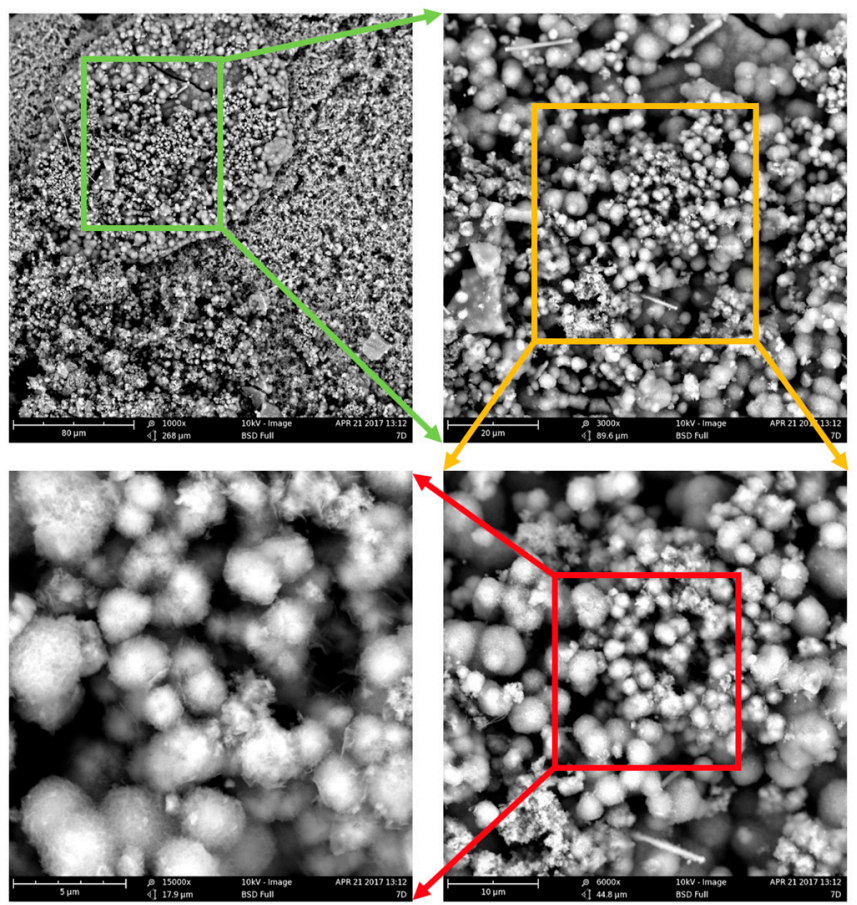

Figure 7. Spherical precipitates imaged with SEM with increasing magnification $(1000 \times, 3000 \times, 6000 \times$, and $15,000 \times$ ). 


\subsubsection{Raman Spectroscopy}

Raman shifts of the unseeded precipitates and the product from the seeded, $7 \mathrm{mM}$ [Pi] precipitation are compared in Figure $8 \mathrm{a}, \mathrm{b}$. There was no evidence of an amorphous calcium phosphate (ACP) phase, which has been associated with a $v_{1}$ phosphate molecule shift at $951 \mathrm{~cm}^{-1}$, nor a $v_{1}$ carbonate shift at $1081 \pm 3 \mathrm{~cm}^{-1}$ for ACP precipitating systems that absorbed ambient carbon dioxide [24]. The dominant precipitate Raman shift is for the $v_{1}$ phosphate molecule shift at $960 \mathrm{~cm}^{-1}$ of apatite, with shifts similar to the $v_{3}$ phosphate molecule attributed at $1041 \pm 3 \mathrm{~cm}^{-1}$, and a $v_{1}$ carbonate shift at $1073 \pm 2 \mathrm{~cm}^{-1}$ [24]. The intensity of the $v_{1}$ carbonate shift was largest for bone mineral and the $7 \mathrm{mM}$ precipitate with homogeneously nucleated seed, which is supported by their larger measured carbonate weight fractions.

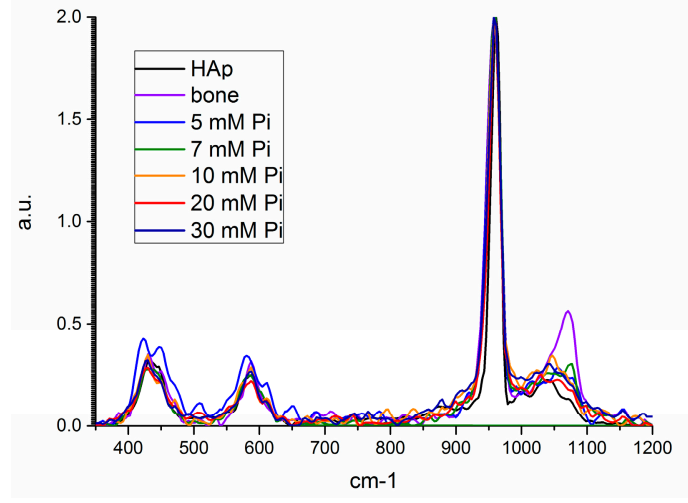

(a)

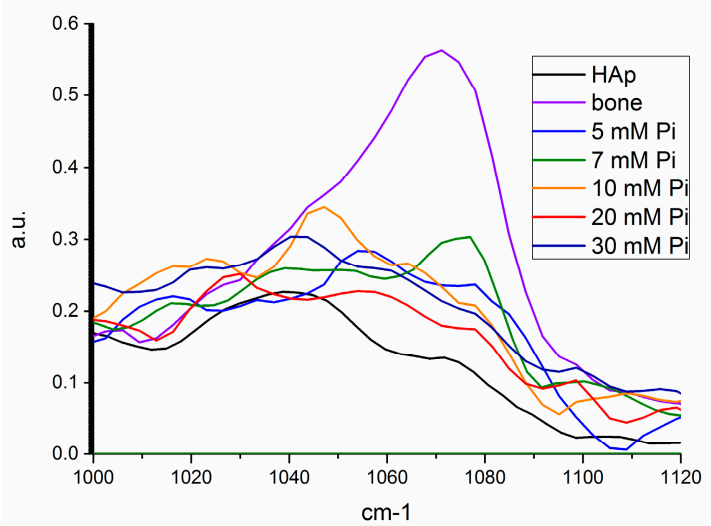

(b)

Figure 8. Raman spectra for synthetic hydroxyapatite (HAP, black), bone mineral (violet), unseeded precipitate from 5 (blue), $10 \mathrm{mM}$ (orange), $20 \mathrm{mM}$ (red), and $30 \mathrm{mM}$ (navy), and $7 \mathrm{mM}$ seeded precipitate (green) from (a) $350-1200 \mathrm{~cm}^{-1}$, and (b) $1000-1120 \mathrm{~cm}^{-1}$.

Raman spectroscopy allowed for the identification of the characteristic P-O shift for phosphate in apatite, and supporting evidence for the measured inorganic carbonate fraction (Section 3.4.4). There was no evidence of calcite, with its $v_{1}$ carbonate shift at $1090 \mathrm{~cm}^{-1}$, or another crystalline phosphate mineral phase that is distinguishable from apatite, such as octacalcium phosphate, brushite, or whitlockite.

\subsubsection{Powder X-ray Diffraction}

Powder X-ray diffraction patterns generated by bone mineral, the $30 \mathrm{mM}$ Pi unseeded experiment, and the seed and precipitate from the $7 \mathrm{mM}$ [Pi] experiment are presented in Figure 9.

These X-ray diffraction patterns are similar in peak position, and are representative of the low intensity and wide shape of biological apatite. This indicates that the precipitates are composed of small polycrystalline domains and/or are poorly crystalline, and/or highly substituted apatite. For orientation, the ICDD powder diffraction file for hydroxyapatite (01-089-4405) is overlaid on the precipitate product data. 


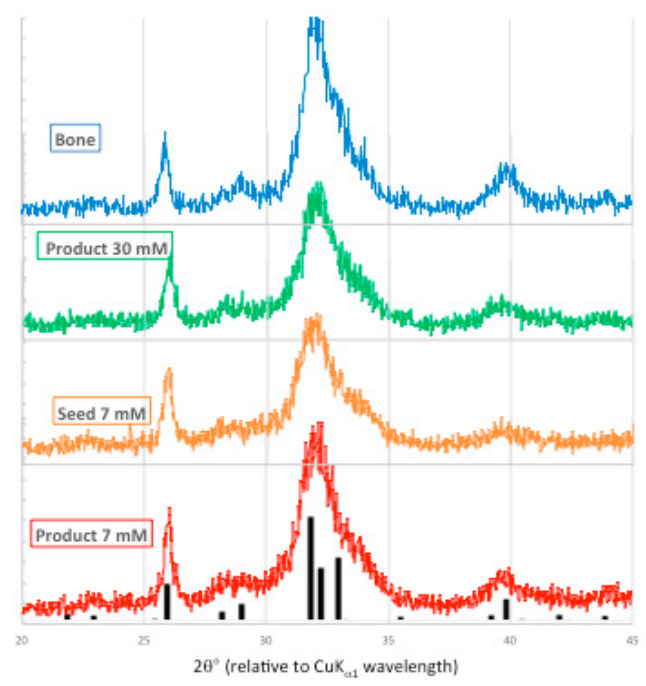

Figure 9. X-ray powder diffraction patterns from bone mineral (blue), $30 \mathrm{mM}$ [Pi] unseeded experiment (green), $7 \mathrm{mM}$ [Pi] seed (orange) and seeded precipitate (red), overlaid with ICDD 01-089-4405 PDF (hydroxyapatite, black).

\subsubsection{Inorganic Carbon Coulometry}

The measured carbonate weight fraction of the unseeded precipitates and the $7 \mathrm{mM}$ [Pi] seeded precipitate are presented in Table 9.

Table 9. Inorganic carbon coulometry measurement of weight percent carbonate $\left(\mathrm{CO}_{3}{ }^{2-}\right)$

\begin{tabular}{ccc}
\hline [Pi] Solution $(\mathbf{m M})$ & [Seed] $\mathbf{g} / \mathbf{L}$ & Weight $\% \mathbf{C O}_{\mathbf{3}}{ }^{2-}$ \\
\hline $5^{1}$ & 0 & $1.95 \pm 0.08$ \\
$7^{2}$ & $1.0(\mathrm{ppt})$ & $2.59 \pm 0.09$ \\
$10^{2}$ & 0 & $1.21 \pm 0.43$ \\
$20^{2}$ & 0 & $1.13 \pm 0.14$ \\
$30^{1}$ & 0 & $1.10 \pm 0.04$ \\
\hline
\end{tabular}

There is a trend of decreasing carbonate weight fraction with increasing initial [Pi] for the unseeded experiments. The carbonate content of the seeded product at $7 \mathrm{mM}$ Pi is higher than the unseeded products. The carbonate weight fraction for the unseeded precipitates are statistically significantly different (one-way ANOVA). The carbonate values for the seeded precipitate and the highest $\mathrm{Ca}-\mathrm{CO}_{3} / \mathrm{Pi}$ ratio (5 $\mathrm{mM}$ initial [Pi]) are within the reported carbonate weight fraction of phosphate rock (1.4-6.3 weight $\% \mathrm{CO}_{3}{ }^{2-}[10]$ ), and are lower than the percent carbonate measured in bone mineral (5-9 weight $\left.\% \mathrm{CO}_{3}{ }^{2-}[28,29]\right)$. These data indicate that carbonate apatite with a carbonate content similar to PR precipitates from mixing solutions with a [Pi] at or lower than $5 \mathrm{mM}$ with saturated $\mathrm{Ca}-\mathrm{CO}_{3}$ solutions in equilibrium with carbon dioxide gas and calcite, without seed, and a solution with $7 \mathrm{mM}$ [Pi] with seed, at room temperature. The carbonate content is less than that for biological apatite. Future work is required to investigate the effect of seed on this carbonate apatite precipitation process.

\subsubsection{Solubility}

Bone mineral was determined to be more soluble that the homogeneously nucleated precipitates, with an equilibrium $\left[\mathrm{Ca}^{2+}\right]$ of $0.34 \mathrm{mM}$, and $[\mathrm{Pi}]$ of $0.13 \mathrm{mM}$. Therefore, samples that contained bone mineral were not included in the comparison of precipitate solubility (Table 10). 
Table 10. Measured dissolved $\left[\mathrm{Ca}^{2+}\right],[\mathrm{Pi}]$, and $\mathrm{Ca} / \mathrm{P}$ in distilled and deionized water compared with $\mathrm{Ca} / \mathrm{P}$ values predicted from the change in precipitating solution composition.

\begin{tabular}{cccccc}
\hline $\begin{array}{c}\text { Initial }[\mathbf{P i}] \\
(\mathbf{m M})\end{array}$ & {$[$ Seed $](\mathbf{g} / \mathbf{L})$} & {$\left[\mathbf{C a}^{2+}\right] \mathbf{( m M )}$} & {$[\mathbf{P i}](\mathbf{m M})$} & $\mathbf{C a} / \mathbf{P}$ & $\begin{array}{c}\mathbf{C a} / \mathbf{P} \\
\text { (Tables } 4 \text { and } 7)\end{array}$ \\
\hline $5^{1}$ & 0 & $0.16 \pm 0.02$ & $0.16 \pm 0.02$ & $1.03 \pm 0.15$ & $1.47 \pm 0.23$ \\
$5^{2}$ & 1.0 & 0.24 & 0.23 & 1.02 & 1.74 \\
$7^{1}$ & 1.0 & $0.21 \pm 0.01$ & $0.22 \pm 0.01$ & $0.97 \pm 0.05$ & $1.52 \pm 0.07$ \\
$10^{1}$ & 0 & $0.18 \pm 0.03$ & $0.23 \pm 0.04$ & $0.79 \pm 0.04$ & $1.46 \pm 0.43$ \\
$20^{1}$ & 0 & $0.18 \pm 0.02$ & $0.51 \pm 0.12$ & $0.38 \pm 0.14$ & $1.08 \pm 0.19$ \\
$30^{3}$ & 0 & $0.17 \pm 0.06$ & $0.45 \pm 0.09$ & $0.39 \pm 0.17$ & $0.48 \pm 0.18$ \\
\hline \multicolumn{7}{c}{${ }^{1} n=4,{ }^{2} n=2,^{3} n=3$}
\end{tabular}

Precipitates grown from previously homogeneously nucleated seed generated the highest average dissolved $\left[\mathrm{Ca}^{2+}\right]$. A one-way ANOVA showed that the average dissolved $\left[\mathrm{Ca}^{2+}\right]$ from the unseeded precipitates did not change significantly with initial [Pi]. Dissolved [Pi] concentrations follow a proportional trend with increasing initial [Pi]. Statistically significant differences between [Pi] means were noted for all groups but not between any two of the 5, 7, and $10 \mathrm{mM}$ Pi groups, and between the 30 and $40 \mathrm{mM}$ Pi groups (Bonferroni test). $\mathrm{Ca} / \mathrm{P}$ ratios for the unseeded and precipitate-seeded experiments followed an inverse trend with the initial [Pi] from which they were nucleated, and have the same statistically significant differences as the final [Pi]. Within the margins of error, a similar trend is seen with the calculated $\mathrm{Ca} / \mathrm{P}$ from the $\left[\mathrm{Ca}^{2+}\right]$ and $[\mathrm{Pi}]$ decrease in the precipitation experiments. The average calculated $\mathrm{Ca} / \mathrm{P}$ values were higher than the measured solubility $\mathrm{Ca} / \mathrm{P}$ values; this may result from the different solution compositions in which the precipitates were in equilibrium, and the effect of the unmeasured carbonate concentrations.

\section{Discussion}

The goal of precipitating a carbonate apatite from industrial-scale solutions with uncontrollable Pi concentrations generated by municipal wastewater treatment requires supersaturated conditions for carbonate apatite. This supersaturation condition could be generated by mixing Pi-rich solutions with dissolved calcium carbonate. The calcium concentrations required to precipitate carbonate apatite from a minimum of $5 \mathrm{mM}$ Pi were generated by increasing calcite solubility with dissolved $\mathrm{CO}_{2}$. Calcium concentrations increased and the $\mathrm{pH}$ decreased by contacting increasing percentages of $\mathrm{CO}_{2}$ gas with synthetic calcite slurried in potable water, up to $6 \pm 1 \mathrm{mM}\left[\mathrm{Ca}^{2+}\right]$. This solution, although unstable when removed from contact $\mathrm{CO}_{2}$, homogeneously nucleated and precipitated carbonate apatite from synthetic solutions with 5-30 mM Pi when mixed in a 1:1 volume ratio. Limestone and combustion flue gas could provide these reagents on the scale of municipal wastewater treatment plants; the effects of other components in these materials remain to be tested.

Unseeded precipitation tests with the highest initial $\left[\mathrm{Ca}^{2+}\right] \times[\mathrm{Pi}]$ values generally produced the lowest final $\left[\mathrm{Ca}^{2+}\right] \times[\mathrm{Pi}]$ values. The seeded tests did not follow this trend; homogeneously nucleated precipitate used as seed resulted in a lower final $\left[\mathrm{Ca}^{2+}\right] \times[\mathrm{Pi}]$ value than bone mineral-seeded experiments. It is not known if this is due to the different carbonate content of the seed minerals, and/or could be attributed to the incongruent dissolution of apatite minerals [31-33]. Further investigation of the effect of seed and its chemistry is required. Seed dissolution and reprecipitation may also affect the equilibrium $\left[\mathrm{Ca}^{2+}\right]$ and $[\mathrm{Pi}]$; this possibility requires further precipitation characterization as a function of time. The disparity between the calculated $\mathrm{Ca} / \mathrm{P}$ precipitate ratios and the measured $\mathrm{Ca} / \mathrm{P}$ dissolved precipitate ratios for the unseeded and seeded products could be explained by the solution carbonate concentrations; these were not measured, and are the subject of future work. The $\mathrm{Ca} / \mathrm{P}$ trend is inversely proportional to the initial [Pi], which suggests a lower carbonate fraction in the precipitate that nucleated from higher [Pi]. This was confirmed with decreasing precipitate carbonate content produced from increasing initial [Pi]. 
$\mathrm{pH}$ was not controlled in these precipitation experiments. An inverse correlation between $\mathrm{pH}$ and percent Pi removed was observed, which suggests that a carbonate apatite precipitation process for Pi removal could be controlled to meet the effluent $[\mathrm{Pi}]$ by increasing the precipitation $\mathrm{pH}$. The different observed relationships between the final $\mathrm{pH}$ of unseeded and seeded experiments and percent $\mathrm{Pi}$ removed suggest that the seed may have affected the solution chemistry. Dissolution of the known higher carbonate content in bone mineral would also increase $\mathrm{pH},\left[\mathrm{Ca}^{2+}\right]$, and [Pi]. Future work will include measuring the dissolved carbonate concentrations before and after precipitation.

Precipitates were characterized as carbonate apatite by Raman spectroscopy and X-ray powder diffraction. Inorganic carbon coulometry confirmed the carbonate content of the samples with 5 and $7 \mathrm{mM}$ initial [Pi] to be within reported carbonate bounds of PR. These samples would have had a higher dissolved carbonate to Pi ratio, and this could have contributed to their higher precipitate carbonate content [34].

The spherical shape of the poorly crystalline carbonated apatite represent a possible different precursor pathway than reported by Habraken et al. [35], as they reported that ACP spheres crystallized to hydroxyapatite plates [35]. However, carbonate ions were not present in significant concentrations in their system. In this work, carbonate concentrations ranging from 1.1-1.95 weight percent were measured in unseeded precipitate; the effect of this carbonate fraction on a potential amorphous calcium carbonate phosphate precursor is not known. It is also possible that initial nuclei resulted in a spherical solid formed of small crystal domains due to a fractal growth pattern [36]. The higher weight percent content in the precipitate produced from $7 \mathrm{mM}$ initial [Pi] with seed produced from homogeneous nucleation is interesting, and will be given future attention. It is not known if the seed changed the solution chemistry, and/or if heterogeneous nucleation may favor a different precipitate chemistry.

Citrate-stabilized, spherical ACP particles in phosphate-buffered saline were observed to generate crystalline apatite domains within the ACP spheres [37]. It is possible that the carbonate ions have impacted the restructuring of the initial, spherical amorphous precursor solids as they transform to a poorly crystalline carbonate apatite, without significantly changing morphology. Carbonate apatite precipitated at $60-85{ }^{\circ} \mathrm{C}$ temperatures exhibited plate morphology with a $c$-axis length of $291.8 \pm 222.0$ at lower carbonate weight percent (3.63 wt \%), and a reduced $c$-axis length of $36.0 \pm 28.4 \mathrm{~nm}$ for 17.8 weight percent carbonate, as measured by TEM [34]. This result also indicates a carbonate effect on apatite crystal habit, although the carbonate apatite precipitation conditions for this work were different than presented here. Seeding with a homogeneously nucleated precipitate resulted in spherical carbonate apatite solids with a significantly higher carbonate content $(2.59 \%)$ when precipitated with a $7 \mathrm{mM}$ [Pi] solution. The effect of seeding with homogeneously nucleated solids on the precipitate characteristics and its carbonate content requires further study.

Zou et al. reported a phase transformation from spherical amorphous calcium carbonate (ACC) to spherical vaterite for smaller $(\sim 100 \mathrm{~nm})$ and more soluble ACC particles, and a dissolution-reprecipitation pathway for larger ACC spheres that generated calcite rhombohedral crystals [38]. We propose that our homogeneous precipitates initially nucleated as soluble, amorphous calcium carbonate phosphate spheres that underwent a phase transformation to carbonated apatite without creating the plate-like crystal habit of apatite. The surface of this spherical, highly substituted carbonate apatite precipitate may enable epitaxial growth of carbonated apatite with a higher carbonate fraction, but further experiments that include initial precipitate characterization, and tracking the change in precipitate size in seeded experiments are required to confirm this hypothesis.

\section{Conclusions}

These precipitation conditions were inspired by the availability of waste phosphate-containing solutions from municipal wastewater treatment plants, carbon dioxide gas, calcium carbonate equilibrium, and the apatite lattice that is tolerant of many substitutions. A saturated solution of potable water, calcite, and carbon dioxide generated a sufficiently high calcium concentration to precipitate carbonate apatite from synthetic phosphate solutions at room temperature that are 
representative of possible phosphate-containing streams from municipal wastewater treatment plants, with or without seed.

When mixed at a 1:1 volume ratio with a $\mathrm{CO}_{2}$-calcium carbonate-saturated solution with a $6 \pm 1 \mathrm{mM}\left[\mathrm{Ca}^{2+}\right]$, the minimum [Pi] to nucleate and grow carbonate apatite was $5 \mathrm{mM}[\mathrm{Pi}]$. Homogeneous nucleation was evident for [Pi] at or greater than $10 \mathrm{mM}$ [Pi]. The unseeded precipitation experiment with highest initial carbonate/phosphate concentration, and the experiment seeded with solids from homogenously nucleated precipitation experiments generated spherical precipitates less than $10 \mu \mathrm{m}$ in size, with some groups producing carbonate fractions similar to phosphate rock. The precipitate weight fraction of carbonate was higher when precipitation occurred in the presence of seed produced from homogeneous nucleation conditions.

The spherical shape of the precipitates and poorly crystalline structure suggest an amorphous precursor that transformed to a poorly crystalline carbonate apatite without significant morphological change. Future work will involve characterizing the first and subsequent solid phases to nucleate in these conditions between initial mixing and the equilibrium state after 5 days, further investigating the effect of seed on this precipitation reaction, and extending these tests to the complex P-containing solutions from municipal wastewater treatment.

Acknowledgments: The Natural Sciences and Research Council of Canada's Discovery Grant program is acknowledge for supporting this research. We thank Professor Fabio Variola for use of his Raman spectrometer, Duane Dukart and Christian Kabbe for guidance and support. Bulat Gabidullin is acknowledged for generating the powder X-ray diffraction data. The reviewers are thanked for their helpful feedback, which improved the manuscript.

Author Contributions: J.R., E.A., and D.S. conceived, designed and performed the precipitation experiments, measured the solution chemistry, and undertook the SEM work. O.M. and L.G. designed and performed the calcium carbonate dissolution experiments. S.O. conceived the project, measured carbonate content with H.M. and J.R., and with J.R., wrote the manuscript.

Conflicts of Interest: The authors declare no conflict of interest.

\section{Appendix A}

SEM summary of products at $500 \times$ magnification. Top row are products of unseeded experiments, in order of increasing initial [Pi]. The bottom row shows the seed, and precipitates formed from seeded experiments. Seed 2 was formed by mixing a solution of $27 \mathrm{mM}$ Pi with a $\mathrm{CO}_{2}$-saturated solution of $\mathrm{CaCO}_{3}$, using the same method as the unseeded tests. It was subsequently used as seed for one of the $5 \mathrm{mM}$ Pi tests. The precipitates formed during both $5 \mathrm{mM}$ Pi seeded tests were combined and used as seed ("Seed 5") for the $7 \mathrm{mM}$ Pi tests.

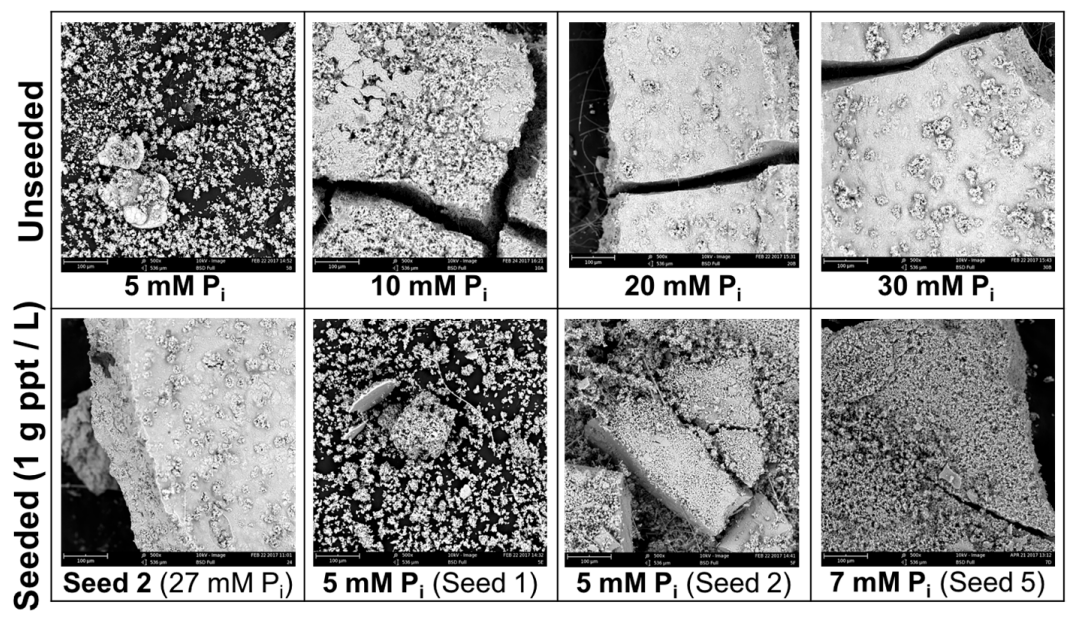

Figure A1. SEM images of precipitates from unseeded and seeded experiments, with the corresponding initial $[\mathrm{Pi}]$ used to produce the precipitate when mixed with saturated $\mathrm{Ca}-\mathrm{CO}_{3}$ solutions. 


\section{References}

1. Kazakov, A. The phosphorite facies and the genesis of phosphorites. USSR Trans. Sci. Inst. Fert. Insetofung 1937, 142, 95-113.

2. McConnell, D. Precipitation of phosphates in sea water. Econ. Geol. 1965, 60, 1059-1062. [CrossRef]

3. Schulz, H.N.; Brinkhoff, T.; Ferdelman, T.G.; Marine, M.H.; Teske, A.; Jorgensen, B.B. Dense populations of a giant sulfur bacterium in namibian shelf sediments. Science 1999, 284, 493-495. [CrossRef] [PubMed]

4. Bruchert, V.; Jorgensen, B.B.; Neumann, K.; Riechmann, D.; Schlosser, M.; Schulz, H. Regulation of bacterial sulfate reduction and hydrogen sulfide fluxes in the central namibian coastal upwelling zone. Geochim. Cosmochim. Acta 2003, 67, 4505-4518. [CrossRef]

5. Goldhammer, T.; Bruchert, V.; Ferdelman, T.G.; Zabel, M. Microbial sequestration of phosphorus in anoxic upwelling sediments. Nat. Geosci. 2010, 3, 557-561. [CrossRef]

6. Schulz, H.N.; Schulz, H.D. Large sulfur bacteria and the formation of phosphorite. Science 2005, 307, 416-418. [CrossRef] [PubMed]

7. Conkright, M.E.; Gregg, W.W.; Levitus, S. Seasonal cycle of phosphate in the open ocean. Deep Sea Res. Part I Oceanogr. Res. Pap. 2000, 47, 159-175. [CrossRef]

8. Sheldon, R.P. Ancient marine phosphorites. Annu. Rev. Earth Planet. Sci. 1981, 9, 251-284. [CrossRef]

9. Dawson, C.J.; Hilton, J. Fertiliser availability in a resource-limited world: Production and recycling of nitrogen and phosphorus. Food Policy 2011, 36, S14-S22. [CrossRef]

10. McArthur, J.M. Francolite geochemistry-Compositional controls during formation, diagenesis, metamorphism and weathering. Geochim. Cosmochim. Acta 1985, 49, 23-35. [CrossRef]

11. World Fertilizer Trends and Outlook to 2019; Food and Agriculture Organization of the United Nations: Rome, Italy, 2016. Available online: www.fao.org/3/a-i5627e.pdf (accessed on 19 June 2017).

12. Cordell, D.; Neset, T.S.S. Phosphorus vulnerability: A qualitative framework for assessing the vulnerability of national and regional food systems to the multi-dimensional stressors of phosphorus scarcity. Glob. Environ. Chang. 2014, 24, 108-122. [CrossRef]

13. Kuba, T.; Smolders, G.; van Loosdrecht, M.C.M.; Heijnen, J.J. Biological phosphorus removal from wastewater by anaerobic-anoxic sequencing batch reactor. Water Sci. Technol. 1993, 27, 241-252.

14. Ulrich, A. Taking stock: Phosphorus supply from natural and anthropogenic pools in the 21st century. Sci. Total Environ. 2016, 542, 1005-1007. [CrossRef] [PubMed]

15. Morse, G.K.; Brett, S.W.; Guy, J.A.; Lester, J.N. Review: Phosphorus removal and recovery technologies. Sci. Total Environ. 1998, 212, 69-81. [CrossRef]

16. Phosphorus and Nitrogen Removal from Municipal Wastewater: Principles and Practice, 2nd ed.; Sedlak, R.I., Ed.; Lewis Publishers: Washington, DC, USA, 1991.

17. Minh, D.P.; Lyczko, N.; Sebei, H.; Nzihou, A.; Sharrock, P. Synthesis of calcium hydroxyapatite from calcium carbonate and different orthophosphate sources: A comparative study. Mater. Sci. Eng. B 2012, 177, 1080-1089. [CrossRef]

18. McKendry, P. Energy production from biomass (part 2): Conversion technologies. Bioresour. Technol. 2002, 83, 47-54. [CrossRef]

19. Kashchiev, D.; van Rosmalen, G.M. Review: Nucleation in solutions revisited. Cryst. Res. Technol. 2003, 38, 555-574. [CrossRef]

20. Songolzadeh, M.; Soleimani, M.; Takht Ravanchi, M.; Songolzadeh, R. Carbon dioxide separation from flue gases: A technological review emphasizing reduction in greenhouse gas emissions. Sci. World J. 2014, 2014, 34. [CrossRef] [PubMed]

21. Kuo, J.; Dow, J. Biogas Production from Anaerobic Digestion of Food Waste and Relevant Air Quality Implications. J. Air. Waste Manag. Assoc. 2017. [CrossRef] [PubMed]

22. Schwarzenbach, G. The complexones and their analytical application. Analyst 1955, 80, 713-729. [CrossRef]

23. Robinson, R.; Roughan, M.E.; Wagstaff, D. Measuring inorganic phosphate without using a reducing agent. Ann. Clin. Biochem. 1971, 8, 168-170. [CrossRef]

24. Kazanci, M.; Fratzl, P.; Klaushofer, K.; Paschalis, E.P. Complementary information on in vitro conversion of amorphous (precursor) calcium phosphate to hydroxyapatite from raman microscopy and wide-angle X-ray scattering. Calcif. Tissue Int. 2006, 79, 354-359. [CrossRef] [PubMed] 
25. Niu, X.; Chen, S.; Tian, F.; Wang, L.; Feng, Q.; Fan, Y. Hydrolytic conversion of amorphous calcium phosphate into apatite accompanied by sustained calcium and orthophosphate ions release. Mater. Sci. Eng. C Mater. Biol. Appl. 2017, 70, 1120-1124. [CrossRef] [PubMed]

26. Morse, J.W. Dissolution kinetics of calcium carbonate in sea water, iii. A new method for the study of carbonate reaction kinetics. Am. J. Sci. 1974, 274, 97-107. [CrossRef]

27. Fleisch, H. Role of nucleation and inhibition in calcification. Clin. Orthop. Relat. Res. 1964, 32, $170-180$. [CrossRef] [PubMed]

28. Penel, G.; Leroy, G.; Rey, C.; Bres, E. Microraman spectral study of the po4 and co3 vibrational modes in synthetic and biological apatites. Calcif. Tissue Int. 1998, 63, 475-481. [CrossRef] [PubMed]

29. Kuhn, L.T.; Grynpas, M.D.; Rey, C.C.; Wu, Y.; Ackerman, J.L.; Glimcher, M.J. A comparison of the physical and chemical differences between cancellous and cortical bovine bone mineral at two ages. Calcif. Tissue Int. 2008, 83, 146-154. [CrossRef] [PubMed]

30. Moradian-Oldak, J.; Weiner, S.; Addadi, L.; Landis, W.J.; Traub, W. Electron imaging and diffraction study of individual crystals of bone, mineralized tendon and synthetic carbonate apatite. Connect. Tissue Res. 1991, 25, 219-228. [CrossRef] [PubMed]

31. Jahnke, R.A. The synthesis and solubility of carbonate fluorapatite. Am. J. Sci. 1984, 284, 58-78. [CrossRef]

32. Perrone, J.; Fourest, B.; Giffaut, E. Surface characterization of synthetic and mineral carbonate fluorapatites. J. Colloid Interface Sci. 2002, 249, 441-452. [CrossRef] [PubMed]

33. Tang, R.; Henneman, Z.J.; Nancollas, G.H. Constant composition kinetics study of carbonated apatite dissolution. J. Cryst. Growth 2003, 249, 614. [CrossRef]

34. Deymier, A.C.; Nair, A.K.; Depalle, B.; Qin, Z.; Arcot, K.; Drouet, C.; Yoder, C.H.; Buehler, M.J.; Thomopoulos, S.; Genin, G.M.; et al. Protein-free formation of bone-like apatite: New insights into the key role of carbonation. Biomaterials 2017, 127, 75-88. [CrossRef] [PubMed]

35. Habraken, W.J.E.M.; Tao, J.; Brylka, L.J.; Friedrich, H.; Bertinetti, L.; Schenk, A.S.; Verch, A.; Dmitrovic, V.; Bomans, P.H.H.; Frederik, P.M.; et al. Ion-association complexes unite classical and non-classical theories for the biomimetic nucleation of calcium phosphate. Nat. Commun. 2013, 4, 1507. [CrossRef] [PubMed]

36. Simon, P.; Schwarz, U.; Kniep, R. Hierarchical architecture and real structure in a biomimetic nano-composite of fluorapatite with gelatine: A model system for steps in dentino- and osteogenesis? J. Mater. Chem. 2005, 15, 4992-4996. [CrossRef]

37. Chatzipanagis, K.; Iafisco, M.; Roncal-Herrero, T.; Bilton, M.; Tampieri, A.; Kroger, R.; Delgado-Lopez, J.M. Crystallization of citrate-stabilized amorphous calcium phosphate to nanocrystalline apatite: A surface-mediated transformation. CrystEngComm 2016, 18, 3170-3173. [CrossRef]

38. Zou, Z.; Bertinetti, L.; Politi, Y.; Jensen, A.C.S.; Weiner, S.; Addadi, L.; Fratzl, P.; Habraken, W.J.E.M. Opposite particle size effect on amorphous calcium carbonate crystallization in water and during heating in air. Chem. Mater. 2015, 27, 4237-4246. [CrossRef]

(C) 2017 by the authors. Licensee MDPI, Basel, Switzerland. This article is an open access article distributed under the terms and conditions of the Creative Commons Attribution (CC BY) license (http:/ / creativecommons.org/licenses/by/4.0/). 